\title{
The influence of albedo parameterization for improved lake ice simulation
}

\author{
Alexis L. Robinson ${ }^{1}$, Sarah S. Ariano ${ }^{2}$, Laura C. Brown ${ }^{1}$ \\ ${ }^{1}$ Department of Geography, University of Toronto Mississauga, Mississauga, L5L 1C6, Canada \\ $5 \quad{ }^{2}$ Department of Geography and Environmental Studies, Ryerson University, Toronto, M5B 1G3, Canada \\ Correspondence to: Alexis L. Robinson (alexis.robinson@mail.utoronto.ca)
}

\begin{abstract}
Lake ice models can be used to study the latitudinal differences of current and projected changes in ice covered lakes under a changing climate. The Canadian Lake Ice Model (CLIMo) is a one-dimensional freshwater ice cover model that simulates Arctic and sub-Arctic lake ice cover well. Modelling ice cover in temperate regions has presented challenges due to

10 the differences in composition between northern and temperate ice. This study presents a comparison of measured and modelled ice regimes, with a focus on refining CLIMo for temperate regions. The study sites include two temperate region lakes (MacDonald Lake and Clear Lake, Central Ontario) and two High Arctic lakes (Resolute Lake and Small Lake, Nunavut) where climate and ice cover information have been recorded over three seasons. The ice cover simulations were validated with a combination of time lapse imagery, field measurements of snow depth, snow density, ice thickness and albedo data, and

15 historical ice records from the Canadian Ice Database (for Resolute Lake). Simulations of the High Arctic ice cover show good agreement with previous studies for ice-on and ice-off dates (MAE 6 to 8 days). Unadjusted simulations for the temperate region lakes show both an underestimation in ice thickness $(\sim 4$ to $18 \mathrm{~cm})$ and ice-off timing ( 25 to 30 days). Field measurements were used to adjust the albedo parameterization used in CLIMo, which resulted in improvements to both simulated ice thickness, within $0.1 \mathrm{~cm}$ to $10 \mathrm{~cm}$ of manual measurements, and ice-off timing, within 1 to 7 days of observations.

20 These findings suggest regionally specific measurements of albedo can improve the accuracy of lake ice simulations.

These results further our knowledge regarding of the response of temperate and High Arctic lake ice regimes to climate conditions.
\end{abstract}

\section{$1 \quad$ Introduction}

Globally, the greatest spatial distribution of freshwater lakes is between $45-75^{\circ} \mathrm{N}$ (Verpoorter et al., 2014) with most of these

25 lakes experiencing some level of ice cover throughout the year. Reported trends in lake ice cover have shown shifts towards shorter ice-covered seasons, with the rates of change depending on the time span examined (e.g. Benson et al., 2012). Longterm trends of Northern Hemisphere lakes project the number of lakes transitioning from annual ice cover to intermittent winter ice cover will increase exponentially with climate warming (Sharma et al., 2019). Regional water and energy balances will likely experience changes as a result of this decreasing ice cover; through changes to the exchange of moisture and gas fluxes 
30 (e.g. increased evaporation), as well as to ecosystems (e.g. earlier lake stratification, warmer summer surface temperatures and increased aquatic productivity) and socio-economic changes (e.g. reduced winter recreation and transportation) (Brown and Duguay, 2010; Benson et al., 2012; Arp et al., 2015; Duguay et al., 2015; Griffiths et al., 2017; Hampton et al., 2017; Hewitt et al., 2018). These changes and their impacts vary spatially, due to latitudinal differences in ice types and how they respond to climate. With northern latitudes warming at a more rapid rate than southern latitudes (AMAP, 2017), the latitudinal response 35 of lake ice becomes even more pertinent.

The dominant controls on ice phenology (ice-off, ice-on, duration) are lake size, air temperature, precipitation, wind speed, and the radiation balance (Brown and Duguay, 2010; Leppäranta, 2015). After formation, ice thickens as a result of conductive heat loss from the warmer water below through the ice/snow cover to the atmosphere, leading to the formation of black ice (Leppäranta, 2015). On-ice snow accumulation can both modify the thickness through insulating properties and 40 contribute to thickening from flooded snow or slush refreezing into the ice sheet as white ice (Brown and Duguay, 2010; Leppäranta, 2015). Additionally, in temperate regions ice thickening through white ice growth has been observed to occur through multiple mid-winter freeze/thaw events (Ariano and Brown, 2019). The albedo of the ice and any overlying snow plays a large role in the ice-off process as ice melt initiation is controlled by albedo, which is a surface property describing the ratio of outgoing to incoming solar radiation (Duguay et al., 2003). Lake ice albedo is affected by snow cover, ice type (e.g.

45 black ice and white ice), ice thickness, the presence of impurities, cloud cover, air temperature and solar zenith angle (Leppäranta, 2015). The light scattering properties of white ice are different than black ice due to the tightly packed air bubbles, which result in a higher albedo (Svacina et al., 2014a; Leppäranta, 2015). Both snow cover and white ice delay ice-off due to the higher albedo compared to the lower albedo of black ice (Svacina et al., 2014a; Leppäranta, 2015), however, when snowfree conditions exist on the ice or moisture is present in the white ice, albedo begins to decrease, and melt occurs. Once snow

50 and ice melt occur, albedo values drop to between 0.7 and 0.25 ; which results in more energy available for melt and creates a positive feedback loop that accelerates the melt process (Heron and Woo, 1994; Henneman and Stefan, 1999; Jakkila et al., 2009; Leppäranta, 2015; Zdorovennova et al., 2018). Studies of lake ice albedo indicate that values can range from 0.10 - 0.85 (Heron and Woo, 1994; Henneman and Stefan, 1999; Jakkila et al., 2009; Semmler et al., 2012; Svacina et al., 2014b; Zdorovennova et al., 2018). In addition, the albedo measured for snow on ice covered lakes ranges between $0.5 \neg 0.95$ (Jakkila 55 et al., 2009; Semmler et al., 2012; Svacina et al., 2014a; Zdorovennova et al., 2018). These studies indicate that lake ice (and overlying snow) albedo values vary temporally and spatially which makes the parameterization of albedo in modelling applications difficult (Lang et al., 2018; Leppäranta, 2015), highlighting the need to better understand and improve the representation of albedo for ice regimes within lake ice models.

Physically based models can be used to simulate ice phenology thickness and to examine the sensitivity of these

60 factors to climate change. (e.g. Brown and Duguay, 2011a; Yang et al., 2012; Cheng et al., 2014). The Canadian Lake Ice Model (CLIMo) has been used successfully for simulating Arctic and sub-Arctic lake ice cover (e.g. Ménard et al., 2002; Duguay et al., 2003; Morris et al., 2005; Brown and Duguay, 2011a, 2011b; Kheyrollah Pour et al., 2012; Surdu et al., 2014). This model uses a thermodynamic approach to determine ice formation, growth and decay; where these processes are 
controlled by an energy surplus or deficit (Brown and Duguay, 2010). However, CLIMo differs from other thermodynamic

65 models through its parameterization of snow conductivity and surface albedo (Duguay et al., 2003). The albedo parameterization in CLIMo is dependent on surface type (ice, snow, or open water), whether the surface temperature is above or below freezing, and the thickness of the ice (Duguay et al., 2003). Currently, albedo is parametrized following Maykut, (1982) for cold conditions and uses observation data from High Arctic lake ice (Heron and Woo, 1994) for melting conditions. These observations were obtained from Small Lake, NU, where the typical ice conditions exceed two metres with a very small

70 amount $(<1 \%-7 \%$, Heron, 1985) of white ice formed at the top of the ice column (white ice was measured at $<4 \%$ of the total ice thickness; Heron, 1985; Ariano and Brown, 2019). In the temperate regions, however, typical ice conditions do not exceed $1 \mathrm{~m}$ and have a much higher amount of white ice. For example, in the Haliburton region of Central Ontario, maximum white ice percentages ranged from 25-73\% of the ice column between 2016 and 2019 (Ariano and Brown, 2019, updated to 2019). Initial model simulations for this region using CLIMo found that ice-off dates were too early, as the large amount of white ice

75 was not accounted for (Ariano, 2017), indicating that the current parameterization of surface albedo in CLIMo is not suitable for temperate lake ice.

This research compares ice cover simulations from High Arctic and temperate region lakes to illustrate the latitudinal differences in lake ice properties and presents refinements to CLIMo to better simulate ice thickness and ice-off timing in the temperate region. The specific objectives of this research were to 1) show the effectiveness of CLIMo for simulating the ice

80 cover regimes of a small $\left(<1 \mathrm{~km}^{2}\right)$ and a medium $\left(1-100 \mathrm{~km}^{2}\right)$ sized High Arctic lakes and 2) investigate and improve the ability of CLIMo to simulate temperate region ice covers using two medium sized lakes in Central Ontario. Understanding the latitudinal differences in lake ice processes, types, and the interactions of climate and lake ice is important for improving climate and lake ice modelling accuracy - which is an essential precursor to providing more robust modelling results of predicted changes.

\section{$852 \quad$ Study Areas}

\subsection{Study Area: High Arctic}

Small Lake and Resolute Lake (Fig. 1a, b, c) are located on Cornwallis Island in Nunavut, Canada. Small Lake (74²45'N, $95^{\circ} 05^{\prime} \mathrm{W}$ ) has a surface area of $0.2 \mathrm{~km} 2$ (Woo, 2012) and a maximum depth of $\sim 10 \mathrm{~m}$ (Heron and Woo, 1994). Ice-off and ice-on, recorded by digital cameras from 2016-2018, occurred late July to early August and early September to late September,

90 respectively. Maximum ice thickness in 1980 and 1981 was $2.42 \mathrm{~m} \pm 0.1 \mathrm{~m}$ and $2.37 \mathrm{~m} \pm 0.1 \mathrm{~m}$, respectively (Heron, 1985) and in May 2016 it was measured at $\sim 1.88 \mathrm{~m}$ with the ice type being composed of almost entirely black ice (Brown, 2016).

Resolute Lake $\left(74.72^{\circ} \mathrm{N}, 94.95^{\circ} \mathrm{W}\right)$ has a surface area of $1.27 \mathrm{~km} 2$ and a maximum depth of $22.5 \mathrm{~m}$ (Lescord et al., 2015). Historical ice date records between 1961-1986 for Resolute Lake are recorded in the Canadian Ice Database (CID) (Lenormand et al., 2002), where ice-off and ice-on occurred late July to late August and early September to early October, 95 respectively. Mean maximum ice thickness measured in June between 1970 to 1982 was 2.13 m (Lenormand et al., 2002). 
Recently, thickness was measured on May 19, 2019 and ranged from 2.1 to 2.4 m (Data collected by Resolute community members).

The location of the Resolute Bay weather station $\left(74^{\circ} 43^{\prime} \mathrm{N}, 94^{\circ} 58^{\prime} \mathrm{W}\right)$ is $\sim 4.9 \mathrm{~km}$ south-east of Small Lake and $\sim 3$ km north of Resolute Lake. The mean climatology (1981-2010) (ECCC, 2017) indicates subfreezing temperatures last for 9 months (from September to May) with a mean winter temperature of $-31.5{ }^{\circ} \mathrm{C}$ and a mean summer temperature of $2.3{ }^{\circ} \mathrm{C}$. Mean snowfall is $111.2 \mathrm{~cm}$; with a mean end of May snow depth of $17 \mathrm{~cm}$ (ECCC, 2017) (used to represent end-of-season snow). However, the representativeness of weather station snowfall to snow accumulation in High Arctic basins has been shown to be under-represented by 130-300\% (Woo et al., 1983; Yang and Woo, 1999). End of season snow surveys on Small Lake (Table 1) completed May 22, 2016 and May 16, 2018 measured mean snow depth on the lake at $17 \mathrm{~cm}$ and $11 \mathrm{~cm}$, respectively. In 1980 and 1981 snow surveys were completed throughout June, with the central part of the lake mean snow depth measuring $0.1 \mathrm{~m}$ or less and the mean snow depth at edges of the lake measuring $1.5 \mathrm{~m}$ or less (Heron, 1985). Finally, the mean snow density for May, extracted from the Canadian Snow Database CD (Snow CD) (which contains gridded snow density normals between 1960 to 1990, Meteorological Service of Canada (MSC), 2000), for the region is $303 \mathrm{~kg} \mathrm{~m}^{-3}$, while the measured on-ice snow density from the snow surveys was $357 \mathrm{~kg} \mathrm{~m}^{-3}$ in 2016 and $308 \mathrm{~kg} \mathrm{~m}^{-3}$ in 2018; slightly higher than on land, as on-ice snow densities are typically higher by $20 \%$ (Sturm and Liston, 2003).

\subsection{Study Area: Temperate}

The temperate study lakes, MacDonald Lake and Clear Lake, are located within the Haliburton Forest and Wild Life Reserve Ltd. $\left(45.12^{\circ} \mathrm{N}, 78.07^{\circ} \mathrm{W}\right)$ in Central Ontario, Canada (Fig. $1 \mathrm{~d}$, e). Haliburton County is located at the southern end of the

115 Precambrian shield, in the Ontario Shield ecoregion, and is defined by a temperate climate and dominated by mixed and deciduous forests (Crins et al., 2009; Hadley et al., 2013). MacDonald Lake has a surface area of $1.56 \mathrm{~km}^{2}$ and a maximum depth of $39.6 \mathrm{~m}$ (mean depth $12.2 \mathrm{~m}$ ) while the surface area of Clear Lake is $1.8 \mathrm{~km}^{2}$ with a maximum depth of $42.7 \mathrm{~m}$ (mean depth $15.2 \mathrm{~m}$ ) (Haliburton Forest and Wild Life Reserve, 2012).

The mean climatology records (1981-2010) (ECCC, 2017) from the nearby Town of Haliburton, Ontario $\left(45.03{ }^{\circ} \mathrm{N}\right.$, $78.53^{\circ} \mathrm{W} ; 22 \mathrm{~km}$ south of the study lakes) show sub-freezing temperatures last for 4 months (December to March) with a mean winter temperature of $-5.0{ }^{\circ} \mathrm{C}$ and a mean summer temperature of $16.6^{\circ} \mathrm{C}$. The mean annual snowfall is $279.6 \mathrm{~cm}$ with a mean end of March snow depth of $16 \mathrm{~cm}$ (ECCC, 2017). On-ice mean snow depth and density for MacDonald Lake and Clear Lake were collected over three field seasons (2016, 2017, and 2018; Table 2) and showed considerable variability throughout all three field seasons. The mean snow depth on the lakes in 2016 was $14 \mathrm{~cm}$; in 2017 it was $12 \mathrm{~cm}$; and in 2018 it was $7 \mathrm{~cm}$. The range of snow densities (Table 2) provided from the Canadian Snow CD (MSC, 2000) indicate mean snow densities of $259 \mathrm{~kg}$ $\mathrm{m}^{-3}$. In comparison, mean field snow densities were $206 \mathrm{~kg} \mathrm{~m}^{-3}, 337 \mathrm{~kg} \mathrm{~m}^{-3}, 328 \mathrm{~kg} \mathrm{~m}^{-3}$ in 2016, 2017 and 2018 , respectively. 
Assessing and comparing simulations to observations of ice cover can be challenging due to the differing definitions used, this paper will follow definitions determined by Brown and Duguay (2011a). The date when simulations form a permanent/complete ice cover for the season is defined as ice-on, with the first day of simulated open water defined as ice-off. The ice-on/off date is defined as the first day when ice/open water is detected above the ice thickness sensor. The camera imagery is subjective since visual assessment and interpretation of ice conditions are impacted by light availability and weather conditions, however, images can be used to identify the freeze-up period, which is defined as the time between when the ice

135 is initially visible in the camera view (freeze-onset) until the formation of solid ice cover (complete ice-on). Surface ice decay can also be identified with camera imagery and is defined by the time when any ice in the camera view is visibly beginning to melt (snow free, wet/slushy surface). The break-up period is defined as the date between the first appearance of open water and when water is completely free of ice (complete ice-off). Dates extracted from the CID represent complete freeze over (iceon) and when the water body is clear of ice (ice-off) (Lenormand et al., 2002).

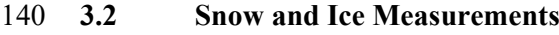

\subsubsection{High Arctic}

Intense data collection is not logistically possible for the High Arctic lakes, however in situ measurements of snow depth and density were measured through end-of-season snow survey’s (Woo, 1997) on Small Lake for May 20, 2016 and May 16, 2018. Sampling transects ranged from 200 to $700 \mathrm{~m}$, snow depth was measured every $10 \mathrm{~m}$ along each transect, with density

145 measurements taken at the start, mid-point and end of each transect. To monitor ice conditions and snow redistribution $-40^{\circ} \mathrm{C}$ rated outdoor digital trail cameras (RECONYX PC800 HyperFire Covert) were installed at each lake. One camera was installed at Small Lake prior to ice-off in May 2016 and a second was installed prior to ice-on at Resolute Lake (Fig. 1) in August 2017. The cameras are in locations selected to maximize field of view of the lake and to allow for accessibility; they capture daily imagery at mid-day to maximize daylight conditions later in the season. No camera imagery was collected for ice-off at Small

150 Lake in 2017 due to a camera power issue. To extend the ice cover record for Resolute Lake, available ice-on and ice-off dates were obtained from the CID from 1960 to 1985. In addition, 1 km Moderate Resolution Imagining Spectroradiometer (MODIS) corrected reflectance (true colour) images from Worldview were used to visually estimate ice-on and ice-off dates between 2000 to 2017 when no observed ice dates are available.

\subsubsection{Temperate}

155 Building from the Ariano and Brown (2019) study, in situ measurements of ice thickness, ice composition, snow depth, and snow density were recorded weekly when ice conditions permitted for the 2015 -2016, 2016-2017 and 2017-2018 field seasons. Four sampling transects (Fig. 1) ranging from 50 - 400 m were established, with two on each study lake; snow depth 
and snow density were measured following the same protocol as on Small Lake. In addition, manual ice thickness measurements were taken along each transect noting the total ice thickness, and the thickness of black and white ice layers. Ice thickness and layer composition were averaged weekly for both each study lake.

Six RECONYX cameras similar to the ones used in the High Artic were installed on trees around the study lakes. Placement of the cameras was selected based on road accessibility and for maximizing the field of view for capturing the snow and ice conditions of the centres and bays of the lakes on an hourly basis (Fig. 1). Continuous ice evolution was monitored using a Shallow Ice Water Profiler (SWIP, ASL Environmental) for the 2016-2017 and 2017-2018 study years, deployed at a depth of $\sim 3 \mathrm{~m}$ in MacDonald Lake, within the field of view of the on-shore AWS for data validation purposes. The SWIP was monitoring the ice thickness every $2 \mathrm{~min}$ and the data were extracted and processed following the similar protocol outlined previously by others (e.g. Melling et al., 1995, Marko et al., 2006, Brown and Duguay 2011a, Ariano and Brown, 2019).

\subsection{Albedo}

170 Detailed albedo was measured by Heron and Woo (1994) and these values form the basis of the melt parameterization currently used in CLIMo (Duguay et al., 2003). For the temperate lakes, surface albedo of the lake ice and on-ice snow were measured on each snow transect (start, middle and end) using a hand-held Solarmeter® Model 10.0 Global Power Meter and averaged for each week (end of the 2018 and throughout the 2019 field campaigns). To obtain the ice albedo, the snow was cleared away from the surface of the ice. During two separate site visits, the ice was snow-free which allowed us to obtain ice surface albedo only (Fig. 2; February 23 and March 2). In addition to the hand-held measurements, a Kipp and Zonen CNR4 net radiometer (measuring downward and upward facing solar radiation in the 0.3 to $2.8 \mu \mathrm{m}$ range every 60 seconds), was mounted and levelled, extended from a dock $1.2 \mathrm{~m}$ above the snow/ice surface on MacDonald Lake (within the 1-2 m above-surface range indicated as ideal by the World Meteorological Organization (WMO, 2008)) for a full season of 8 dates in 2019. Albedo values were calculated by dividing the total reflected shortwave radiation by the total incoming shortwave radiation during daylight hours.

\subsection{Lake Ice Model}

A full description of CLIMo can be found in Duguay et al. (2003), while this abridged description follows our own papers; Brown and Duguay (2011a), Brown and Duguay (2011b), Svacina et al. (2014), and Gunn et al. (2015). CLIMo has been adapted from the one-dimensional thermodynamic sea-ice model of Flato and Brown (1996) which is based on the onedimensional unsteady heat conduction equation, with penetrating solar radiation, of Maykut and Untersteiner (1971):

$\rho C_{p} \frac{\partial T}{\partial t}=\frac{\partial}{\partial z} k \frac{\partial T}{\partial z}+F_{S W} I_{0}(1-\alpha) K e^{-K}$ 
Where Duguay et al. (2003) define the following variables as: $\rho\left(\mathrm{kg} \mathrm{m}^{-3}\right)$ is the density, the specific heat capacity is $C_{p}\left(\mathrm{~J} \mathrm{~kg}^{-}\right.$ $\left.{ }^{1} \mathrm{~K}^{-1}\right), \mathrm{T}(\mathrm{K})$ is the temperature $(\mathrm{T}(z, \mathrm{t})$ is the temperature within the ice or snow, $\mathrm{t}$ is time $(\mathrm{s})$ and $\mathrm{z}$ is depth measured positive downward $(\mathrm{m})$ from the upper surface), $\mathrm{t}(\mathrm{s})$ is the time, $k\left(\mathrm{Wm}^{-1} \mathrm{~K}^{-1}\right)$ is the thermal conductivity, $\mathrm{F}_{\mathrm{sw}}\left(\mathrm{Wm}^{-2}\right)$ is the downwelling shortwave radiative energy flux that penetrates the surface, $I_{0}$ is the fraction of shortwave flux that penetrates the surface (equal to 0.17 if snow depth is $\leq 0.01 \mathrm{~m}$ and equal to 0 if snow depth $>0.1 \mathrm{~m}$ ), $\alpha$ is the surface albedo and $\mathrm{K}$ is the bulk extinction coefficient for penetrating shortwave radiation $\left(\mathrm{m}^{-1}\right)$.

To determine the net heat flux absorbed at the surface, the surface energy budget is calculated using:

$F_{0}=F_{l w}-\varepsilon \sigma T_{s}^{4}(0, t)+(1-\alpha)\left(1-I_{0}\right) F_{s w}+F_{\text {lat }}+F_{\text {sens }}$

where $\mathrm{F}_{0}\left(\mathrm{Wm}^{-2}\right)$ is the net downward heat flux absorbed at the surface, $\varepsilon$ is the surface emissivity, $\sigma$ is the Stefan-Boltzmann constant $\left(5.67 \times 10^{-8} \mathrm{Wm}^{-2} \mathrm{~K}^{-4}\right), \mathrm{F}_{\mathrm{lw}}\left(\mathrm{Wm}^{-2}\right)$ is the downwelling longwave radiative flux, $\mathrm{F}_{\mathrm{sw}}\left(\mathrm{Wm}^{-2}\right)$ is the downwelling shortwave radiative flux, $\mathrm{F}_{\text {lat }}\left(\mathrm{Wm}^{-2}\right)$ is the latent heat flux and $\mathrm{F}_{\text {sens }}\left(\mathrm{Wm}^{-2}\right)$ is the sensible heat flux (Duguay et al., 2003). The downward longwave energy flux is calculated using the formula of Maykut and Church (1973), $\mathrm{F}_{\text {lat }}\left(\mathrm{Wm}^{-2}\right)$ and $\mathrm{F}_{\text {sens }}\left(\mathrm{Wm}^{-2}\right)$ are the latent heat flux and sensible heat flux, respectively (both are positive downward) (Flato and Brown, 1996; Ménard et al., 2002; Morris et al., 2005; Brown and Duguay, 2011a).

\subsubsection{Albedo parameterization}

An important component of the surface energy balance calculation used in CLIMo is albedo and it is used to determine ice melt and ice-off dates. As discussed earlier, CLIMo's surface albedo parameterization considers surface type, surface temperature and ice thickness. The surface albedo parameterization is summarized by Duguay et al. (2003) and Svacina et al.

$\alpha=\left\{\begin{array}{lll}\alpha_{\text {ow }} & h_{i}<h_{\text {min }} & \\ \min \left(\alpha_{s}, \alpha_{i}+\frac{h\left(\alpha_{s}-\alpha_{i}\right)}{0.1 m}\right) & h_{i} \geq h_{\min } \quad h_{s}>0.1 \mathrm{~m} \\ \alpha_{s} & h_{i} \geq h_{\min } & \end{array}\right.$

$\alpha_{i}= \begin{cases}\max \left(\alpha_{o w}, 0.44 m^{-0.28} h_{i}^{0.28}+0.08\right) & \mathrm{T}(0, t)<T_{m} \\ \min \left(\alpha_{\mathrm{mi}}, 0.075 m^{-2} h_{i}^{2}+0.15\right) & \mathrm{T}(0, t)=T_{m}\end{cases}$

$\alpha_{s}=\left\{\begin{array}{cc}0.75 & \mathrm{~T}(0, t)<T_{m} \\ 0.65 & \mathrm{~T}(0, \mathrm{t})=T_{m}\end{array}\right.$

where $\alpha$ is surface albedo, $\alpha_{\mathrm{ow}}$ is albedo of open water (0.05), $\alpha_{\mathrm{s}}$ is the albedo of snow, $\alpha_{\mathrm{mi}}$ is the albedo of melting ice (0.55), $210 \alpha_{\mathrm{i}}$ is the ice albedo, $h_{\mathrm{i}}$ is ice thickness $(\mathrm{m}), h_{\min }$ is minimum ice thickness below which open water is assumed $(0.001 \mathrm{~m}), h_{\mathrm{s}}$ is 
snow thickness $(\mathrm{m}), \mathrm{T}(0, \mathrm{t})$ is the temperature within ice or snow at the vertical coordinate 0 at the time $\mathrm{t}(\mathrm{s})$, $\mathrm{T}_{m}$ is melting temperature at the surface $(273.15 \mathrm{~K}) ; 0.1 \mathrm{~m}, 0.44 \mathrm{~m}^{-0.28}$ and $0.075 \mathrm{~m}^{-2}$ are derived from various field observations of ice thickness and radiative flux, which were documented by Maykut (1982) for cold ice. Equation (3) uses ice and snow thickness to determine the albedo value, whereas Eqs. (4) and (5) determine the value of both snow and ice albedo. The strong albedo dependence of young ice on thickness is approximated in Eq. (3) and this has been derived from the observations of Weller (1972) on the radiation balance over sea ice. The melting ice parameterization is based on Arctic lake ice observations from Heron and Woo (1994) (at Small Lake), which has a larger proportion of black ice and therefore, a lower albedo than what would be found at the white ice dominated temperate lakes (Ariano and Brown, 2019).

\subsection{Simulations}

220 The simulations for Resolute Lake were run from 1958 to 2018 to match the ice record length from the CID (1958-1990) and the digital camera record (2017-2018), whereas, the simulations for Small Lake were run from 2016 to 2018 to match the record from the digital camera imagery. The model was driven by daily meteorological data obtained from Environment and Climate Change Canada (ECCC) (Table 3). Improved ice cover simulations are produced when snow density values monitored over the season are used over a fixed average value for the cold season and melt (Brown and Duguay, 2011a). This approach was followed here, with bi-weekly density obtained from the Snow CD (MSC, 2000). The May end-of-season mean on-ice snow density measured May 2016 and 2018 at Small Lake (307 $\mathrm{kg} \mathrm{m}^{-3}$ ) is similar to the late May (May 15-31) value in the Snow CD $\left(303 \mathrm{kgm}^{-3}\right)$, which lends confidence to using the historical snow density values for the entire simulation period. Snow redistribution is prominent for Arctic lakes, with highly variable snow depths common across the lake surface, typically with less snow on-ice than is measured on land at local weather stations (e.g. Woo et al., 1983; Yang and Woo, 1999; Woo and Young, 2004). Comparing the end-of-season snow depths measured at the Resolute weather station to Small Lake in 2016 and 2018 on the same days shows that only $65 \%$ and $40 \%$ of the station snow depth was measured on the ice. Both snow surveys had mean snow depths below the mean annual snow depth of $21 \mathrm{~cm}$ with the on-ice snow depths in May 2016 and May 2018 having standard deviations of $11.8 \mathrm{~cm}$ and $21.5 \mathrm{~cm}$ (respectively); suggesting large snow depth variations across the lake. To represent snow redistribution throughout the season two snow accumulation scenarios were used: $50 \%$, to represent

235 the average amount of snow cover on the ice (and align with previous research for these lakes, Brown and Duguay, 2011b), and $0 \%$ to represent the maximum redistribution possible.

The model simulations for MacDonald Lake and Clear Lake were driven by daily onshore meteorological data (Table 3) from an AWS, located at the southwestern end of MacDonald Lake (Fig. 1d). Cloud cover was obtained for 2015 to 2018 from $1 \mathrm{~km}$ MODIS satellite imagery (MOD08_D3: daily mean cloud fraction) as no nearby ECCC stations collect cloud cover information. Snow density was represented by the actual snow conditions on site. While on-lake snow density is typically denser than that measured on land (Sturm \& Liston, 2003), the Snow CD (MSC, 2000) density values were not representative of current on-lake snow processes (Table 2), so field-measured densities were used in the simulations. Snow redistribution across the lake surface was accounted for by the snow cover scenarios for both MacDonald Lake and Clear Lake, which were 
simulated by determining the mean snow redistribution percentage (the difference between snow accumulation on shore and the measured on-lake snow depth). The scenarios used for 2015-2016, 2016-2017 and 2017-2018 are 47\%, 19\%, and 24\%, respectively. Additionally, to be able to validate CLIMo's simulated ice thickness with the SWIP, the mixing depth was set to $3 \mathrm{~m}$ for MacDonald Lake (and $6 \mathrm{~m}$ for Clear Lake, since it is a slightly larger and deeper lake).

Finally, to better represent the temperate ice cover, albedo values in Eqs. (4) and (5) were adjusted using measured on-lake snow and ice albedo values from the 2017-2018 and 2018-2019 field seasons. Pre-melt ice albedo was determined January - March 2019 (excluding February 1 and February 8 due to rain events), where the albedo ranged from 0.71 to 0.84 (Fig. 4). Pre-melt ice albedo was set to a constant value of 0.75 (average value) in lieu of non-melt in Eq (4), as testing showed the measured albedo of the temperate region white ice was much higher than the existing parameterization accounted for. For example, using a range of $10-50 \mathrm{~cm}$ ice thickness returns albedos in the range of only $\sim 0.3-0.44$ with the existing parameterization. During the melt period identified by Henneman and Stefan (1999) for a temperate lake in Minnesota USA, including the days with fresh snowfalls, the average melt albedo was $\sim 0.5$ to 0.6 , which is a similar range to our record during the melt season, where our average albedo was 0.56 in 2019 under a mix of melting and snow days (March 8, 15, 22, 29 and April 5, after this point we could not sample on the ice). As the melt parameterization in CLIMo is based on black ice, simulations were run using a fixed albedo of 0.56 in lieu of the melting ice albedo in Eq. (4) to represent our ice cover. The existing maximum melt albedo in CLIMo is 0.55 and simulations using our melt albedo value of 0.56 yielded virtually the same simulation results as using the existing maximum melt albedo of 0.55 (same thickness and ice-off timing). Average snow albedo was determined from the 2019 field season between January - March 8, 2019 (excluding mid and late March due to substantial slushing events on the lakes). Multiple snowfalls occurred through the season, with fresh snow (within 1-3 days) on the ice most weeks. The average snow albedo was 0.82 and the effects of using the field-based value on the ice simulations were investigated by altering the albedo by $+/-0.03$, half of the standard deviation. Increasing the snow albedo yielded better ice-off dates, however, for the study year 2015-2016 the snow albedo was increased to 0.88 to better predict ice-off dates as this season had more early-season snow on the ice. Since the results were similar using $0.55 \mathrm{vs}$. 0.56 , this research kept the existing value of 0.55 as our field data consists of only five records; more detailed work should be conducted on melt season albedo in temperate latitudes to build a larger sample size. In addition, pre-melt snow albedo in Eq. (5) was also adjusted to better capture the influence of more frequent fresh snowfalls (fresh snow was present during most site visits each field season) that occur in temperate than in the Arctic (increased from 0.75 to either 0.85 or 0.88 based on snow conditions). We did not investigate altering the melting snow albedo beyond the existing parametrization in CLIMo (set deduction of 0.1 from the nonmelt albedo), as only cold snow or slush were present on the ice during the sampling days. Similar to the melting ice albedo, further investigation into the albedo of melting on-ice snow in temperate regions should also be explored as a future research direction. 


\section{$275 \quad 3.6 \quad$ Model Performance}

For datasets with more than 20 records, model performance was measured using the Index of Agreement in the R package 'HydroGOF' (Ia; standardized measure of the degree of model prediction error which varies between 0 and 1 , where 1 indicates perfect agreement; Willmott, 1981; Zambrano-Bigiarini, 2017) and statistical errors were measured using Mean Bias Error (MBE; determines the systematic errors that occur and identifies if the values are being over- or under-estimated) and Mean

280 Absolute Error (MAE; an absolute measure of the average magnitude of errors, with 0 indicating no error) in the R package 'tdr'(Lamigueiro, 2018). For smaller datasets, only statistical errors could be assessed using MAE.

\section{$4 \quad$ Results and Discussion}

\subsection{Model Simulations - High Arctic}

Simulations for ice-on at Small Lake correctly captured the observed first presence of ice for 2016 (September 12) and was within 1 day of the observed ice for 2017 (September 8, 2017; Fig. 3, Table 4 \& 5). The initial ice cover that formed was subsequently broken-up by wave action (visible in the camera imagery), resulting in the final ice-on date occurring 14 days later in 2016 and 4 days later in 2017. High wind speeds are often recorded in Resolute. CLIMo simulations return thermodynamic ice formation dates, hence the wind driven break-up events in this region were not captured (wind speed is used for the bulk formulae in the surface energy budget determination).

Ice-off simulations are heavily dependent on snow cover and a range of dates are framed by the two simulations. Simulations for 2016 showed ice-off on July 19 and 27 for 50\% snow and no snow respectively, with observations indicating ice free conditions by July 21. Ice-off was simulated slightly later than observations in 2017, August 8 and 15, with observed ice-free conditions by August 1. The 2018 ice-off simulations indicated ice-free on July 27 and August 10, with the observed ice-free conditions occurring August 6. Open water can be observed in the camera imagery near the lake edges in mid-June as snowmelt runoff pools on the ice at the shore, forming a moat, and initiating near-shore melt. However, large floating ice pans can persist until late July or early August; on Small Lake the floating ice pans melted, and open water conditions coincide well with simulated ice-off. For the three ice-off seasons simulated, the average error was 6 days (50\% snow cover) and 8 days (no snow cover).

Resolute Lake (Fig. 4) also shows good agreement between observed and simulated complete ice-on dates (Table 6), with an Ia of 0.65 for $50 \%$ snow cover and 0.79 for no snow, a MBE of -3 and -4 days, respectively, which indicates a slight underprediction (earlier complete ice-on), and a MAE of 6 days for both snow cover simulations. Overall, the observed complete ice-on dates from the CID are modelled within 0 to 17 days of the observed complete ice-on dates, 0 to 7 days of the estimated MODIS imagery, and the camera imagery from 2017-2018 depicts complete ice-on within in 2 to 3 days of the simulated complete freeze-over. The MODIS imagery dates tend to slightly overestimate ice-on due to extensive cloud cover which obscures the ice processes, but the annual variability is in line with the model simulations. 
The simulated ice-off dates for Resolute Lake using the 50\% snow cover scenario are within 1 - 15 days of observations and within 26 days for the no snow scenario. The digital camera imagery in 2017 shows matching ice-off dates with the 50\% scenario, while the no snow scenario, which would have grown thicker ice with no insulating snow overtop, simulates ice-off 7 days later. The estimated dates from the MODIS imagery are within 0 to 25 days and predominantly later than the simulations, which is not unexpected as extensive cloud cover in the region can persist for consecutive days, obscuring the actual ice off date. Despite some years with large differences between the simulations and the observations, the results show a good yearto-year fit with an Ia of 0.75 for $50 \%$ snow cover and 0.77 for no snow cover scenarios. The ice-off for the $50 \%$ snow cover and no snow cover scenarios indicate an MBE of -2 days and 7 days respectively, and a MAE of 8 days for both scenarios (Table 6). These results show that the simulations vary between underprediction and over prediction, which is likely linked to annual snow cover variability, and the occasional presence of residual ice pans. Resolute Lake is larger and deeper than Small Lake and can experience floating ice pans that remain later into the summer than on Small Lake, or in some cases persist through the summer and freeze into the new ice that forms in the fall. While ice pans were observed in both 2016 and 2017 (e.g. Fig. 5), records from the CID do not indicate the presence of residual ice pans which could lead to some discrepancy between the recorded ice-off dates and the simulations.

Using an average value of 50\% snow cover to represent the long-term snow redistribution aims to represent a suitable amount of snow redistribution over the last 60 years. Using the snow survey data from the two available seasons (Table 1) on Small Lake can highlight the redistribution as evidenced through the large standard deviation recorded-particularly 2018 (11 $\mathrm{cm}$ mean, $21.5 \mathrm{~cm} \mathrm{SD})$. The range of on-ice snow depths $(0-154 \mathrm{~cm})$ indicates snow free in some regions and in other regions depth exceeding $100 \%$ of the on-land values in other down-wind (2018 only) and near-shore regions. The uncertainties in the snow conditions of a given year attributed to redistribution are difficult to capture using one snow cover scenario and can result in the range of ice-off dates between snow cover scenarios.

Overall, the results of the simulations of ice-on and ice-off for both lakes, show agreement with previous studies from high latitude lakes where these studies simulated ice-on from 0 to 15 days and 1 to 10 days for ice-off, with the range affected by the snow cover scenarios (Ménard et al., 2002; Duguay et al., 2003; Jeffries et al., 2005; Brown and Duguay, 2011 b).

\subsection{Unadjusted Model Simulations - Temperate}

Ice thickness and phenology were initially simulated using the unadjusted CLIMo for MacDonald and Clear Lakes using the snow depth differences (percentage of on-shore compared to on-lake snow depth) determined for each study year (Table 1) and the measured snow density (field density).The simulations are compared to observations for each year at two transects on each lake and provided in Fig. 6 (red line). Ice-on for MacDonald Lake was simulated well for the three seasons with an overall MAE of 1 day compared to the camera imagery and 2 days compared to the SWIP (Table 7). Ice-on at Clear Lake was not simulated as well, with a MAE of 10 days for the 3 seasons (Table 8). This larger error is suspected to be a result of the selected mixing depth representing deeper regions of the lake than where the cameras are capturing imagery in the shallower bays (where ice-on would likely occur a few days sooner). 
Ice thickness is underpredicted (Fig. 6, Table 9) for both MacDonald and Clear Lake during 2015-2016, 2016-2017

340 and 2017-2018. Ice thickness for MacDonald Lake in comparison to the SWIP (Table 10) is $11.2 \mathrm{~cm}$ and $18.1 \mathrm{~cm}$ for 20162017 and 2017-2018 respectively. In comparison to the observed thickness, MacDonald Lake has a mean MAE of $4.7 \mathrm{~cm}$ and Clear Lake has a mean MAE of $8.4 \mathrm{~cm}$ for the entire study period (2016-2018). Spatial variability is evident when comparing the manual measurements to the simulations and the SWIP, highlighting the thickness variability across the lakes. The overall error was within $7 \mathrm{~cm}$ to the manual measurements, however, the end of season thickness was not included in the manual measurements (e.g. Fig. 6, manual measurements ceased before maximum thickness) and the large discrepancy in the thickness values becomes evident when compared with the SWIP (Fig. 6, Table 10). Furthermore, ice-off simulations were very poor (Table $7 \& 8$ ) with overall errors approaching 4 weeks ( 25 - 28 days), clearly showing both ice thickness and ice-off dates are not representative of these temperate lake sites.

The white ice formed in the temperate region presents a challenge within CLIMo with regards to adequately simulating thickness throughout the ice-covered season, since the model does not currently include the contributions of midwinter rain or meltwater refreeze on the ice. The current black ice (Arctic-based) parameterization also contributed to underpredicting ice-off dates because the expected black ice (versus the actual white ice) has a lower albedo, which results in a more rapid melt once underway. Therefore, to adequately represent ice thickness and melt simulations in the temperate region with CLIMo, the albedo needs to be parameterized using field data that is representative of temperate lakes.

\section{$355 \quad 4.3 \quad$ Adjusted Model Simulations - Temperate}

Initially, changes were only made to the albedo of the ice during melt to explore the relationship between the white ice and the melt rate and ice-off timing. While the results improved, this adjustment did not fully address the underprediction of thickness and ice-off timing. Therefore, further simulations were run using an adjusted albedo parameterization of both snow and ice (Supplementary Fig. S1 \& Fig. 6; dark blue line), with the ice albedo being the dominant driver of the improvements. These results were compared to the original unadjusted simulations.

Tables 7 through 10 highlight the substantial improvement to the model fit for the two temperate lakes. For MacDonald Lake ice-off improved greatly from a MAE of 25 (SWIP) and 28 (digital camera) days to 0.5 and 4 days. Clear Lake still shows some variation in the ice-on results, ranging from 1 to 13 days (MAE = 7, Table 8), however ice-off improved substantially from a MAE of 30 days to 2 days. Simulated thickness improved substantially, with MAE values ranging from

$3652.0-4.5 \mathrm{~cm}$ across both lakes.

Due to unusually high snow depths in early in the 2015-2016 season compared to the other seasons (Ariano and Brown, 2019), the snow albedo was set to 0.88 for this season to better represent both deeper earlier season snow that accumulated on the ice and the multiple fresh snowfall events that occurred in mid-February and early March. For MacDonald Lake (Fig. 6), model improvements simulated ice-on January 4th, which is the same date as observed. Ice thickness throughout these field season fell between observed ice thickness data points which indicates a good agreement of the model to the observed data. The MAE for ice thickness improved from $6.7 \mathrm{~cm}$ to $3.0 \mathrm{~cm}$ to $3.5 \mathrm{~cm}$ and $1.4 \mathrm{~cm}$ respectively for each transect 
on MacDonald Lake (Table 9). With regards to Clear Lake (2015-16), ice thickness simulations showed a reduce average error, from $8.6 \mathrm{~cm}$ to $4.8 \mathrm{~cm}$ and $7.2 \mathrm{~cm}$ to $3.1 \mathrm{~cm}$ for the two transects. Some variation in the MAE for ice thickness is to be expected, as it would be attributed to spatial variability across the lake (from on-ice snow or bathometry variations), which would not be captured by the 1-D model. For comparison, using the snow albedo of 0.85 to be consistent with the other seasons yielded an increased MAE of 1 to $1.5 \mathrm{~cm}$ and an earlier ice-off date of 5 to 7 days.

Model adjustments for 2016-2017 and 2017-2018 (snow albedo $=0.85$ ) show a marked improvement for ice thickness compared to the SWIP data, with the Ia increasing to 0.98 and 0.92 (Table 10) in 2016-2017 and 2017-2018 respectively, with the end of season thickness now well represented. The ice thickness when compared to the transects shows a MAE of $3.7 \mathrm{~cm}$ and $4.9 \mathrm{~cm}$ in 2016-2017 and slightly thicker at 6.8 and $6.1 \mathrm{~cm}$ in 2017-2018. The increase in thickness could be attributed to increased ice growth in the simulations due to colder than normal winter temperatures and less snow cover in January and late February. With regards to Clear Lake, the MAE improved to $2 \mathrm{~cm}$ or less for the 2016-2017 and 2017-2018 seasons (Table 9). In 2017-2018 the winter was initially colder and there were several warming events (with periods of rain) through the season. The adjusted simulation for MacDonald Lake shows good agreement with ice-on and iceoff dates but ice thickness is slightly over-predicted compared to the SWIP (MBE of 1.9) and the observed field measurements (MAE of 6.8 for M1 and 6.1 for M2) are attributed to the spatial variation of ice thickness, as well as the colder temperatures and reduced snow cover $(<5 \mathrm{~cm})$ early in the winter season. Additionally, the simulations did not capture the increased thickness at the end of season to $>65 \mathrm{~cm}$. The end of season cumulative rainfall for the month of March (69 mm) and runoff from the $11.4 \mathrm{~km} 2$ catchment, may have contributed to an increase in observed ice growth monitored in 2018 by the SWIP when the weight of the wet snow depressed the ice cover. However, after this brief thickening, the melt rate and timing are very similar between the simulations and the SWIP.

The unadjusted model results indicate earlier ice-off dates, which we attribute to the lower albedo of black ice parameterized in the model, and hence does not account for the delay in ice melt attributed to the predominantly white ice. This supports the work by Ashton (1986) which states that snow-ice (white ice) slows the ice thinning rate during the early melt season. By utilizing field-based parameterization values of ice and snow albedos in the adjusted simulations, ice decay and ice-off timing are substantially delayed in the ice-cover season, resulting in much better representation of temperate region ice.

\section{$5 \quad$ Summary and Conclusion}

The results demonstrate the relationship between snow and ice composition on the simulation of lake ice formation, growth, and decay of both High Arctic and temperate region lake ice using the Canadian Lake Ice Model. The High Arctic sites show good agreement to ice phenology dates, with a MAE of 6 days for ice-on and 8 days for ice-off for both snow cover scenarios (thickness could not be assessed since it was not recorded). Initial CLIMo simulations of two temperate lakes indicated ice-on dates within 1 to 10 days and ice-off dates of 25 to 30 days. Ice thickness was underpredicted by up to $13.7 \mathrm{~cm}$ on MacDonald 
Lake. The initial results highlighted issues with the representation of the melt period within the model for temperate regions where more white ice is present (Ariano and Brown, 2019). Adjustments to CLIMo used field measured albedo values for snow and ice on temperate lakes and provided dramatically improved simulations of ice thickness and ice-off dates. The adjusted simulations for ice-on had a MAE within 1 to 7 days and ice-off had a MAE of 1 to 4 days. Simulated ice thickness over the 2016-2017 and 2017-2018 seasons improved from Ia of 0.62 to 0.98 and 0.50 to 0.92 respectively and was within 2.7 to $7.2 \mathrm{~cm}$ of the SWIP (MAE). Ice thickness compared to observations for all three seasons had a MAE within 2.0 to 4.5

$410 \mathrm{~cm}$. The albedo of temperate region snow and ice were all increased to better represent the frequent fresh snowfalls and large amounts of white ice that are found in the temperate region. The higher albedo values reflect more incoming radiation, which reduces the absorption of solar radiation into the ice cover and delays the simulated melt onset by approximately 1 month which produces much more realistic results for this region. Overall, this research found that the surface albedo is critical to represent correctly at temperate latitudes because of the impacts ice thickness, the timing of melt onset, and the final ice-off

415 dates. However, further investigation should also be completed regarding the effects of ice thickness on albedo, especially in regions where white ice is dominant. It is important to understand how ice characteristics and cover are changing in temperate latitudes, since freshwater lake abundance is highest within these latitudes (Verpoorter et al., 2014) and temperature projections suggest the number of lakes transitioning from annual to intermittent winter ice cover will increase exponentially with climate warming (Sharma et al., 2019). The ability to model lake ice cover with greater accuracy, including the correct representation of the ice column, is a large stride towards a better understanding the feedbacks between lake ice to climate, in the years to come.

Data Availability. The data that support the findings of this study are available from the corresponding author (ALR) upon reasonable request.

Funding information. Canada Foundation for Innovation / Ontario Research Funds (Brown), Grant/ Award 34864; NSERC Discovery Grant (Brown), Grant/Award Number: 5316; UTM Department of Geography Graduate Expansion Funds (Robinson/Ariano); Northern Scientific Training Program (NSTP) (Robinson, 2017, 2018; Ariano, 2016); Haliburton Forest and Wild Life Reserve Ltd.(in kind) and Polar Continental Shelf Program (PCSP) (logistical support, in kind).

Author contributions. AR and LB designed the study, SA and AR carried out the principle field component with guidance and supervision from LB. AR and SA were involved in data curation and formal analysis including running preliminary model simulations for the High Arctic and Temperate study site, respectively. AR modified the model code using in-situ field data for the adjusted Temperate lake simulations. AR prepared the primary manuscript with contributions from all co-authors. LB 435 and AR were also responsible for visualization of data for publication.

Competing interests. The authors declare that they have no conflict of interest. 
Acknowledgements. This project was funded by an NSERC Discovery Grant (Brown), CFI/ORF (Brown), UTM Department

of Geography Graduate Expansion Funds (Robinson/Ariano), Northern Scientific Training Program (Robinson/Ariano) and the Polar Continental Shelf Program (Brown). We would like to thank Haliburton Forest and Wild Life Reserve Ltd. for their in-kind support and overall assistance with this project. We would also like to thank Kathy Young, Scott Lamoureux, Laura Thomson, Anna Pienkowski-Furze, Dana Stephenson, Debbie Iqaluk, Sean Yokoyama, Evan Thompson, Justin Murfitt, Alicia Dauginis, William Sturch and the Qarmartalik School for field assistance. We also appreciate the assistance / advice from ASL

445 Environmental and Mike Brady (Environment and Climate Change Canada).

\section{References}

AMAP.: Snow, Water, Ice and Permafrost in the Arctic (SWIPA) 2017, Arctic Monitoring and Assessment Programme (AMAP), Oslo, Norway: Arctic Monitoring and Assessment Programme (AMAP), 269 pp., https://doi.org/10.1029/2002WR001512, 2017.

Ariano, S. S.: An investigation of temperate region lake ice in Central Ontario, M.Sc thesis, University of Toronto, Toronto, Ont., 2017.

Ariano, S. S., and Brown, L. C.: Ice processes on medium-sized north-temperate lakes, Hydrol. Process, 33, 2434- 2448, https://doi.org/10.1002/hyp.13481, 2019.

Arp, C. D., Jones, B. M., Liljedahl, A. K., Hinkel, K. M., and Welker, J. A.: Depth, ice thickness, and ice-out timing cause divergent hydrologic responses among Arctic lakes, Water Resour. Res, 51, 9379-9401, https://doi.org/10.1002/2015WR017273, 2015.

Ashton, G. D.: River and lake ice engineering, Littleton, Colo., U.S.A: Water Resources Publications, Littleton, Colo, U.S.A. 1986.

Benson, B. J., Magnuson, J. J., Jensen, O. P., Card, V. M., Hodgkins, G., Korhonen, J., Granin, N. G.: Extreme events, trends, and variability in Northern Hemisphere lake-ice phenology (1855-2005), Climatic Change, 112(2), 299-323, https://doi.org/10.1007/s10584-011-0212-8, 2012.

Brown, L. C.: Unpublished Data, 2016.

Brown, L. C., and Duguay, C. R.: The response and role of ice cover in lake-climate interactions, Prog Phys Geog, 34(5), 671-704, https://doi.org/10.1177/0309133310375653, 2010.

465 Brown, L. C., and Duguay, C. R.: A comparison of simulated and measured lake ice thickness using a Shallow Water Ice Profiler, Hydrol. Process, 25(19), 2932-2941, https://doi.org/10.1002/hyp.8087, 2011 a.

Brown, L. C., and Duguay, C. R.: The fate of lake ice in the North American Arctic, The Cryosphere, 5(4), 869-892, https://doi.org/10.5194/tc-5-869-2011, 2011 b. 
Cheng, B., Vihma, T., Rontu, L., Kontu, A., Pour, H.K., Duguay, C. and Pulliainen, J.: Evolution of snow and ice temperature, thickness and energy balance in Lake Orajärvi, northern Finland, Tellus A, 66(1), 21564, https://doi.org/10.3402/tellusa.v66.21564, 2014.

Crins, W. J., Gray, P. A., Uhlig, P. W. C., and Wester, M. C. The Ecosystems of Ontario, Part 1: Ecozones and Ecoregions, Ministry of Natural Resources, Peterborough, ON., 71 pp., 2009.

Duguay, C. R., Bernier, M., Gauthier, Y., and Kouraev, A.: Remote Sensing of lake and river ice, in: Remote Sensing of the Cryosphere, edited by: Tedesco, M., Wiley Blackwell, Hoboken, NJ, 273-306, http://doi.ogr/10.1002/9781118368909.ch12, 2015.

Duguay, C. R., Flato, G. M., Jeffries, M. O., Ménard, P., Morris, K., and Rouse, W. R.: Ice-cover variability on shallow lakes at high latitudes: model simulations and observations, Hydrol. Process, 17(17), 3465-3483, https://doi.org/10.1002/hyp.1394, 2003.

Environment and Climate Change Canada (ECCC).: Canadian Climate Normals 1981 - 2010, Ottawa, Canada, https://climate.weather.gc.ca/climate_normals/, 2017.

Flato, G. M., and Brown, R. D.: Variability and climate sensitivity of landfast Arctic sea ice, J. Geophys. Res., 101(C11), 25767-25777, https://doi.org/10.1029/96JC02431, 1996.

Gunn, G. E., Duguay, C. R., Brown, L.C., King, J., Atwood, D., Kasurak, A.: Freshwater lake ice thickness derived using Xand Ku-band FMCW scatterometers in the Hudson Bay Lowlands Near Churchill, Manitoba. Cold Reg. Sci. Technol, 120, 115-126, https://doi.org/10.1016/j.coldregions.2015.09.012, 2015.

Griffiths, K., Michelutti, N., Sugar, M., Douglas, M. S. V, and Smol, J. P.: Ice-cover is the principal driver of ecological change in High Arctic lakes and ponds, PLoS ONE , 12(3), 1-25, https://doi.org/10.1371/journal.pone.0172989, 2017.

Hadley, K. R., Paterson, A. M., Hall, R. I., and Smol, J. P.: Effects of multiple stressors on lakes in south-central Ontario: 15 years of change in lakewater chemistry and sedimentary diatom assemblages, Aquat. Sci., 75, 349-360, https://doi.org/10.1007/s00027-012-0280-5, 2013.

Haliburton Forest and Wild Life Reserve.: Haliburton Forest 4th Edition Fishing Guide, Haliburton, Canada: Haliburton Forest and Wild Life Reserve Ltd, 2012.

Hampton, S. E., Galloway, A. W., Powers, S. M., Ozersky, T., Woo, K. H., Batt, R. D., Labou, S. G., O'Reilly, C. M., Sharma, S., Lottig, N. R. and Stanley, E. H.: Ecology under lake ice, Ecol. Lett., 20, 98-111, https://doi.org/10.1111/ele.12699, 2017

Henneman, H. E., and Stefan, H. G.: Albedo models for snow and ice on a freshwater lake, Cold Reg. Sci. Technol., 29, 3148, https://doi.org/10.1016/S0165-232X(99)00002-6, 1999.

Heron, R.: Decay of a High Arctic lake ice cover, Ph.D. thesis, Department of Biology, McMaster University, Hamilton, On., 178 pp., 1985.

Heron, R., and Woo, M. K.: Decay of a High Arctic lake-ice cover: observations and modelling, J. Glaciol., 40(135), 283-292, https://doi.org /10.3189/S0022143000007371, 1994. 
Hewitt, B. A., Lopez, L. S., Gaibisels, K. M., Murdoch, A., Higgins, S. N., Magnuson, J. J., Paterson, A. M., Rusak, J. A., Yao, H. and Sharma, S.: Historical trends, drivers, and future projections of ice phenology in small North Temperate Lakes in the Laurentian Great Lakes Region, Water, 10(2), 70, https://doi.org/10.3390/w10010070, 2018.

Jakkila, J., Leppäranta, M., Kawamura, T., Shirasawa, K. and Salonen, K.: Radiation transfer and heat budget during the ice season in Lake Pääjärvi, Finland, Aquat. Ecol., 43(3), 681-692, https://doi.org/10.1007/s10452-009-9275-2, 2009.

Jeffries, M. O., Morris, K., and Duguay, C. R.: Lake ice growth and decay in central Alaska, USA: observations and computer simulations compared, Ann. Glaciol., 40, 195-199, https://doi.org /10.3189/172756405781813807, 2005.

Kheyrollah Pour, H., Duguay, C. R., Martynov, A., and Brown, L. C.: Simulation of surface temperature and ice cover of large northern lakes with 1-D models: A comparison with MODIS satellite data and in situ measurements, Tellus A, 64(1), 119, https://doi.org/10.3402/tellusa.v64i0.17614, 2012.

Lamigueiro, O.P.: tdr:Target Diagram Package, CRAN, https://cran.r-project.org/web/packages/tdr/index.html , 2018.

Lang, J., Lyu, S., Li, Z., Ma, Y., and Su, D.: An investigation of the ice surface albedo and its influence on the High-Altitude lakes of the Tibetan Plateau, Remote Sens., 10 (218), 1-17, http://doi.org/10.3390/rs10020218, 2018.

Lenormand, F., Duguay, C. R., and Gauthier, R.: Development of a historical ice database for the study of climate change in Canada, Hydrol. Process, 16, 3707-3722, https://doi.org/10.1002/hyp.1235, 2002.

Leppäranta, M.: Freezing of Lakes and the Evolution of their Ice Cover. Freezing of Lakes and the Evolution of their Ice Cover, Springer, Berlin, Heidelberg, Germany, 2015.

Lescord, G. L., Kidd, K. A., Kirk, J. L., O’Driscoll, N. J., Wang, X., and Muir, D. C. G.: Factors affecting biotic mercury concentrations and biomagnification through lake food webs in the Canadian high Arctic, Sci. Total Environ., 509, 195205, https://doi.org/10.1016/j.scitotenv.2014.04.133, 2015.

Marko, J. R., Fissel, D. B., and Jasek, M.: Recent developments in ice and water column profiling technology, in: Proceedings from the 18th IAHR symposium on river ice, Sapporo, Japan, 28 August - 1 September 2006, 8pp., 2006

Maykut, G. A.: Large-scale heat exchange and ice production in the Central Arctic, J. Geophys. Res-Oceans, 87(C10), 79717984, https://doi.org/10.1029/JC087iC10p07971, 1982

Maykut, G. A., and Church, P. E.: Radiation climate of Barrow, Alaska, 1962-66, J. Appl. Meteorol., 12, 620-628, https://doi.org/10.1175/1520-0450(1973)012<0620:RCOBA>2.0.CO;2, 1973.

Maykut, G. A., and Untersteiner, N.: Some results from a time-dependent thermodynamic model of sea ice, J. Geophys. ResOceans, 76(6), 1550-1575, https://doi.org/10.1029/JC076i006p01550, 1971.

Melling, H., Johnston, P. H., and Riedel, D. A.: Measurements of the underside topography of sea ice by moored subsea sonar, J. Atmos. Ocean Tech., 12, 589-602, https://doi.org/10.1175/1520-0426(1995)012<0589:MOTUTO>2.0.CO;2, 1995.

Ménard, P., Duguay, C. R., Flato, G. M., and Rouse, W. R.: Simulation of ice phenology on a large lake in the Mackenzie River Basin (1960-2000), in: 59th Eastern Snow Conference, Stowe, Vt., USA, 5-7 June, 2002.

MSC (Meteorological Service of Canada).: Canadian Snow Data CD-ROM: Daily Snow Depth and Snow Water Equivalent. Climate Processes and Earth Observation Division, MSC, Downsview, Ontario, Canada: Environment Canada, 2000. 
Morris, K., Jeffries, M., and Duguay, C. R.: Model simulation of the effects of climate variability and change on lake ice in central Alaska, USA., Ann. Glaciol., 40, 1-6, https://oi.org/10.3189/1727564057818136632005.

Natural Resources Canada: Website: https:/open.canada.ca/data/en/dataset/7f245e4d-76c2-4caa-951a-45d1d2051333, 2015.

Semmler, T., Cheng, B., Yang, Y., and Rontu, L.: Snow and ice on Bear Lake (Alaska) sensitivity experiments with two lake ice models, Tellus A, 64(1), 1-14, https://doi.org/10.3402/tellusa.v64i0.17339, 2012.

Sharma, S., Blagrave, K., Magnuson, J. J., O’Reilly, C. M., Oliver, S., Batt, R. D., Magee, M. R., Straile, D., Weyhenmeyer, G. A., Winslow, L. and Woolway, R. I.: Widespread loss of lake ice around the Northern Hemisphere in a warming world, Nat. Clim. Change, 9, 227-231, https://doi.org/10.1038/s41558-018-0393-5, 2019.

545 Statistics Canada: Website: https://www12.statcan.gc.ca/census-recensement/2011/geo/bound-limit/bound-limit-2016eng.cfm, 2016.

Sturm, M., and Liston, G. E.: The snow cover on lakes of the Arctic Coastal Plain of Alaska, U.S.A., J. Glaciol., 49(166), 370380, https://doi.org/10.3189/172756503781830539, 2003.

Surdu, C. M., Duguay, C. R., Brown, L. C., and Fernández Prieto, D.: Response of ice cover on shallow lakes of the North Slope of Alaska to contemporary climate conditions (1950-2011): Radar remote-sensing and numerical modeling data analysis, The Cryosphere, 8(1), 167-180, https://doi.org/10.5194/tc-8-167-2014, 2014.

Svacina, N. A., Duguay, C. R., and Brown, L. C.: Modelled and satellite-derived surface albedo of lake ice - Part I: evaluation of the albedo parameterization scheme of the Canadian Lake Ice Model, Hydrol. Process, 28, 4550-4561, https://doi.org/10.1002/hyp.10253, 2014a.

555 Svacina, N. A., Duguay, C. R., and King, J. M. L.: Modelled and satellite-derived surface albedo of lake ice - part II: evaluation of MODIS albedo products, Hydrol. Process, 28(16), 4562-4572, https://doi.org/10.1002/hyp.10257, 2014b.

Weller, G.: Radiation flux investigation, Arctic Ice Dynamics Joint Experiment (AIDJEX) Bulletin, 14, 28-30, 1972.

Willmott, C. J.: On the validation of models, Phys. Geogr., 2, 184-194, https://doi.org/10.1080/02723646.1981.10642213, 1981.

WMO (World Meteorological Organization).: Guide to Meteorological Instruments and Methods of Observation: WMO-No 8 (7th ed.), Geneva, Switzerland: World Meteorological Organization, 2008.

Woo, M. K., Heron, R., Marsh, P., and Steer, P.: Comparison of weather station snowfall with winter snow accumulation in high arctic basins, Atmos. Ocean, 21(3), 312-325. https://doi.org/10.1080/07055900.1983.9649171, 1983.

Woo, M. K., and Heron, R.: Freeze-up and break-up of ice cover on small arctic lakes, in: Northern Lakes and Rivers, edited by: Mackay, W.C., Boreal Institute for Northern Studies, Edmonton, AB, 56-62, 1989.

Woo, M. K., and Young, K. L.: Modeling arctic snow distribution and melt at the $1 \mathrm{~km}$ grid scale*, Nord. Hydrol., 35(4-5), 295-307, https://doi.org/10.2166/nh.2004.0022, 2004.

Woo, M. K.: Permafrost Hydrology, Springer-Verlag, Heidelberg, Germany, 2012.

Verpoorter, C., Kutser, T., Seekell, D. A., and Tranvik, L. J.: A global inventory of lakes based on high-resolution satellite imagery, Geophys. Res. Lett., 41(18), 6396-6402, https://doi.org/10.1002/2014GL060641, 2014. 
https://doi.org/10.5194/hess-2020-156

Preprint. Discussion started: 27 April 2020

(c) Author(s) 2020. CC BY 4.0 License.

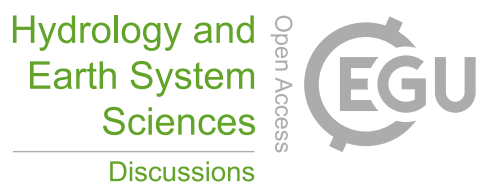

Yang, D., and Woo, M. K.: Representativeness of local snow data for large scale hydrologic investigations, Hydrol. Process, 13, 1977-1988, https://doi.org/10.1002/(SICI)1099-1085(199909)13:12/13<1977::AID-HYP894>3.0.CO;2-B, 1999.

Yang, Y., Leppäranta, M., Cheng, B., and Li, Z.: Numerical modelling of snow and ice thicknesses in Lake Vanajavesi, Finland, Tellus A, 64(1), 17202, https://doi.org/10.3402/tellusa.v64i0.17202, 2012.

Zdorovennova, G., Palshin, N., Efremova, T., Zdorovennov, R., Gavrilenko, G., Volkov, S., Bogdanov, S. and Terzhevik, A.: Albedo of a small ice-covered boreal lake: daily, meso-scale and interannual variability on the background of regional climate, Geosci. J., 8(6), 206, https://doi.org/10.3390/geosciences8060206, 2018.

Zambrano-Bigirarini, M.: hydroGOF: Goodness-of-fit functions for comparison of simulated and observed hydrological time series, https://cran.r-project.org/web/packages/hydroGOF/, 2017. 


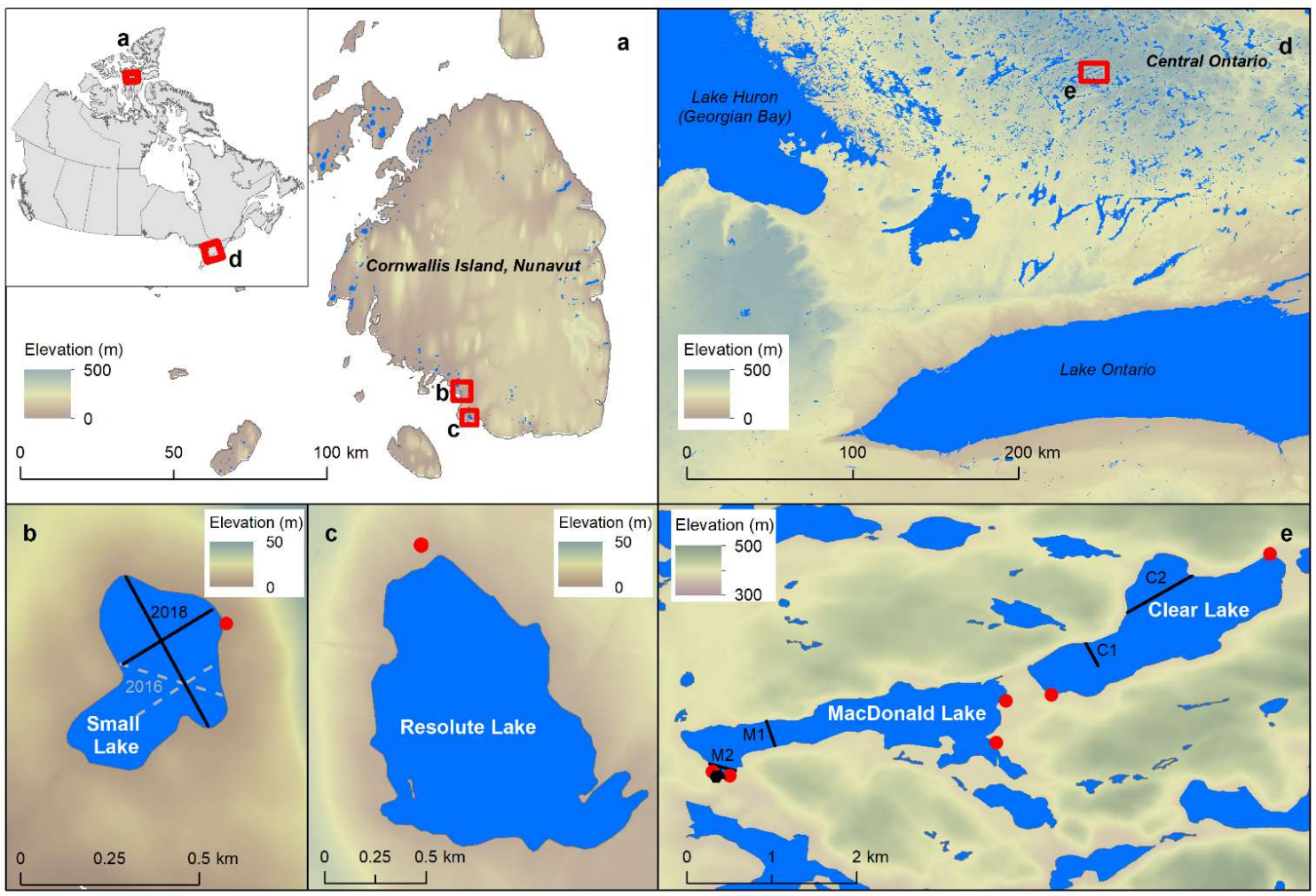

- Digital camera locations

_ Sampling transects: Small Lake snow surveys (grey dashed line - 2016, black solid line - 2018)

MacDonald and Clear Lakes weekly snow, ice and albedo sampling

Figure 1. Location of field sites in Canada; High Arctic field sites (a) with zoom in (b) Small Lake and (c) Resolute Lake, Cornwallis Island, Nunavut; temperate field sites (d) with zoom in (e) MacDonald Lake and Clear Lake, Ontario. MacDonald Lake Automated Weather Station noted with Black circle at M2; Shallow Water Ice Profiler (SWIP) is also located at M2. Base map and lake boundaries (C) Statistics Canada (2016) and Canadian digital elevation model (C) Natural Resouces Canada (2015). 
https://doi.org/10.5194/hess-2020-156

Preprint. Discussion started: 27 April 2020

(c) Author(s) 2020. CC BY 4.0 License.

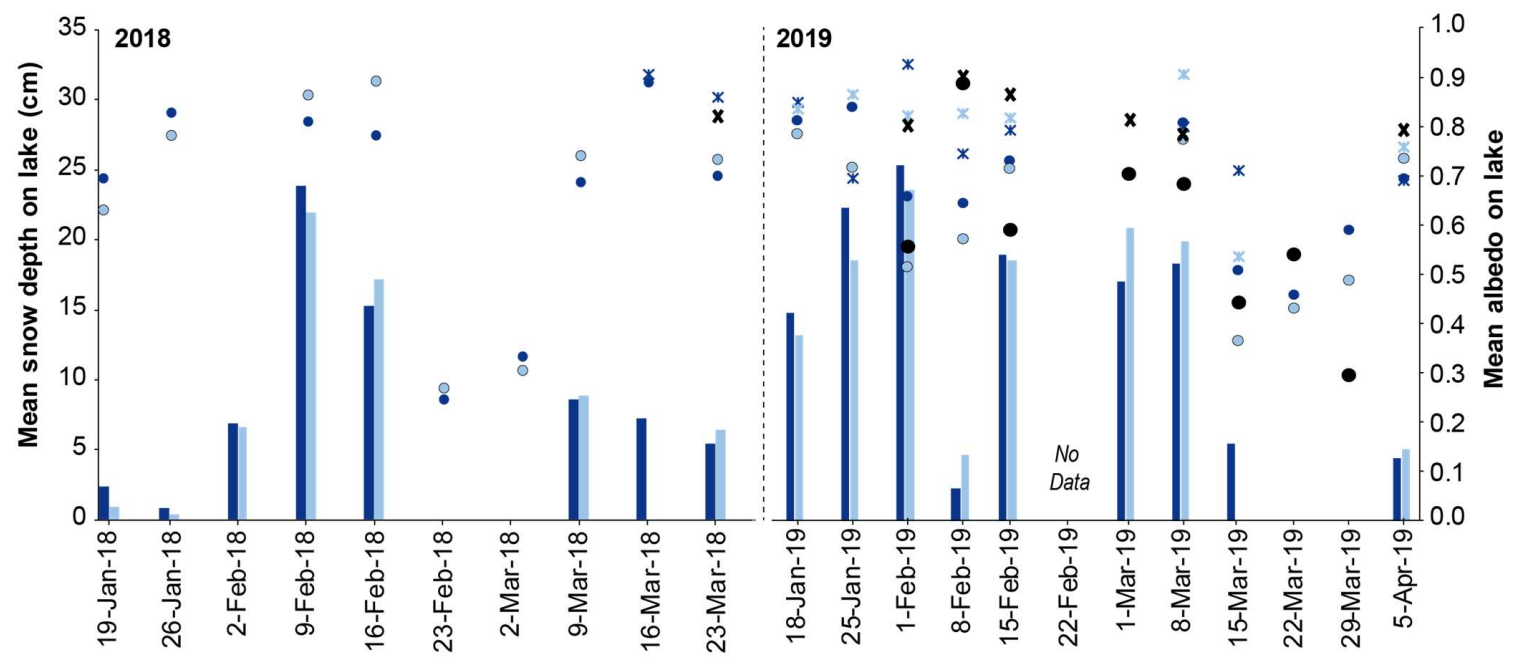

Mean Snow Depth (cm) Snow Albedo

- MacDonald Lake x MacDonald Lake (CNR4)

Ice Albedo

" Clear Lake

* MacDonald Lake

- MacDonald Lake (CNR4)

- MacDonald Lake

- Clear Lake

Figure 2. Point measurements of lake ice albedo (2018 and 2019), on-ice snow albedo (2019), ice and snow albedo from the CNR4 (2019) and mean transect snow depths (2018 and 2019) from MacDonald Lake and Clear Lake.

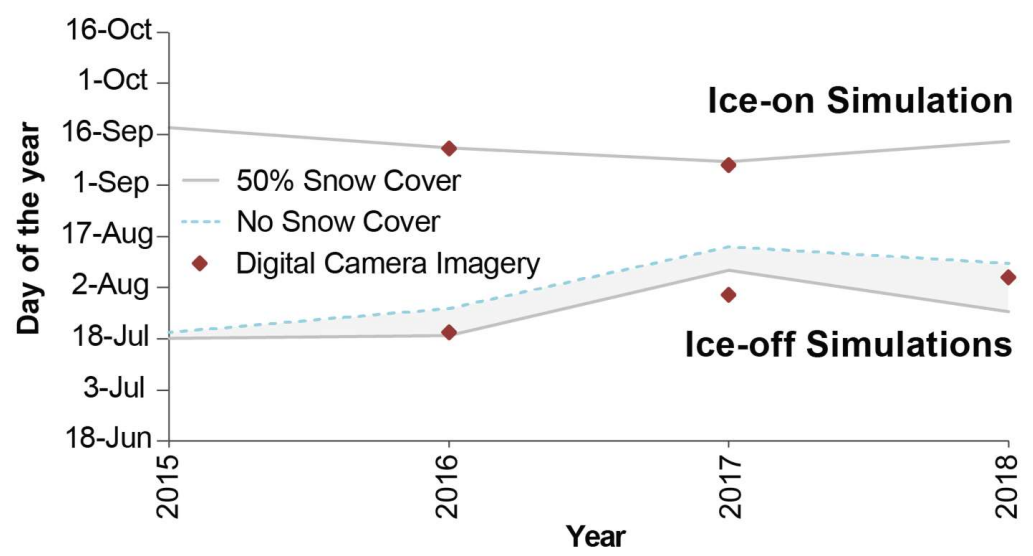

Figure 3. Simulated ice-on and ice-off dates between 2015 and 2018 for Small Lake, NU compared with the observed ice-on and iceoff dates from the digital camera 2016-2018. 


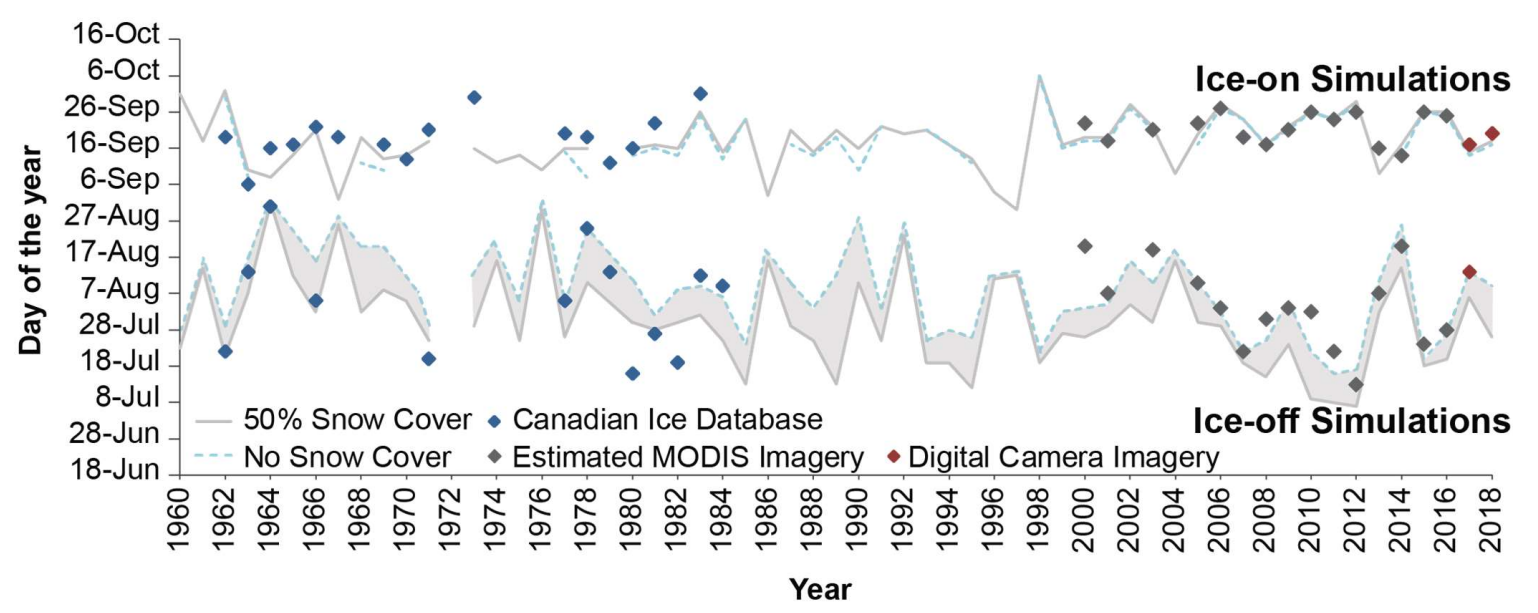

Figure 4. Comparison between simulated ice-on and ice-off dates and those observed from the CID (1961-1986) and digital camera (2017-2018) for Resolute Lake, NU. Note, no ice-off (and therefore no ice-on) was simulated for 1972 with either scenario. Estimated ice-on and ice-off dates from MODIS imagery (2000-2018) are added for visual comparison but are not included in subsequent statistics as cloud cover results in substantial uncertainty.

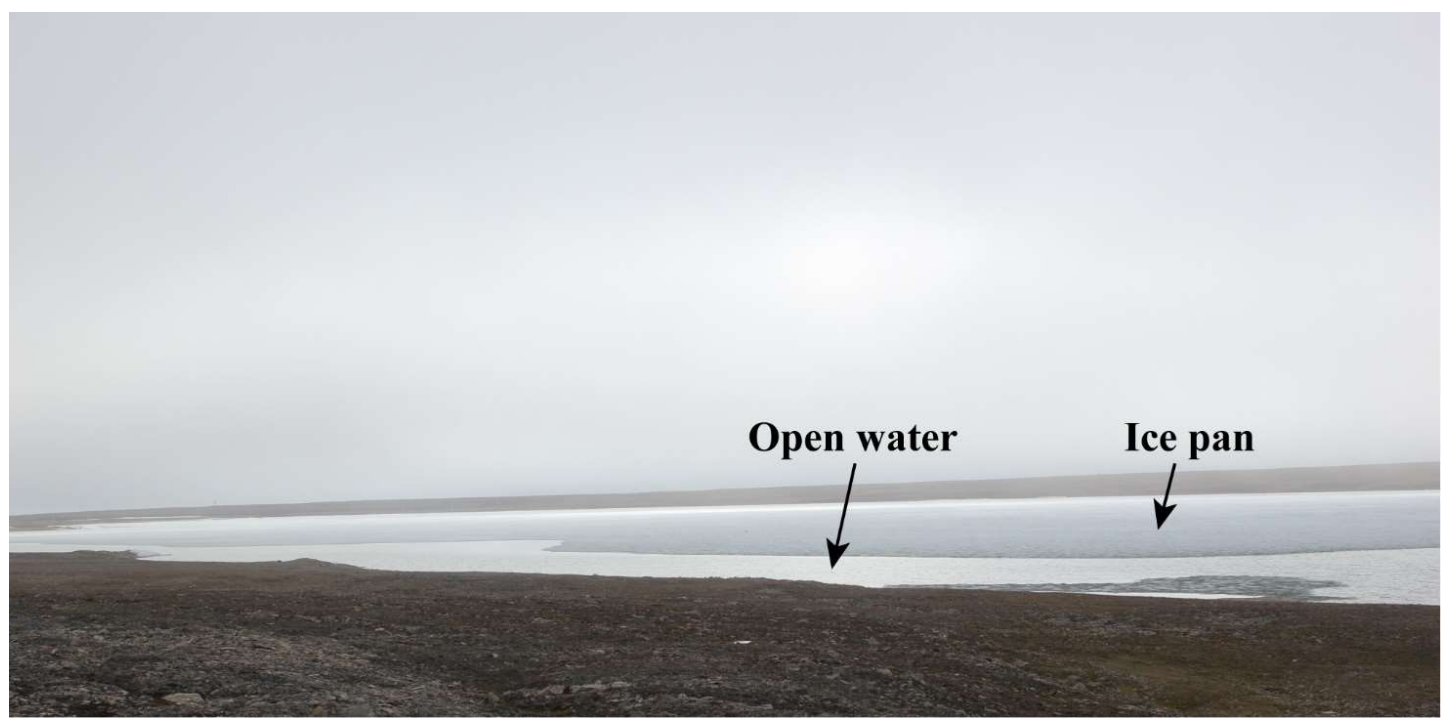

Figure 5. Photograph of Resolute Lake taken August 8, 2018, labelled to show the difference between open water area and the ice pan at the north end of the lake. 
https://doi.org/10.5194/hess-2020-156

Preprint. Discussion started: 27 April 2020

(c) Author(s) 2020. CC BY 4.0 License.

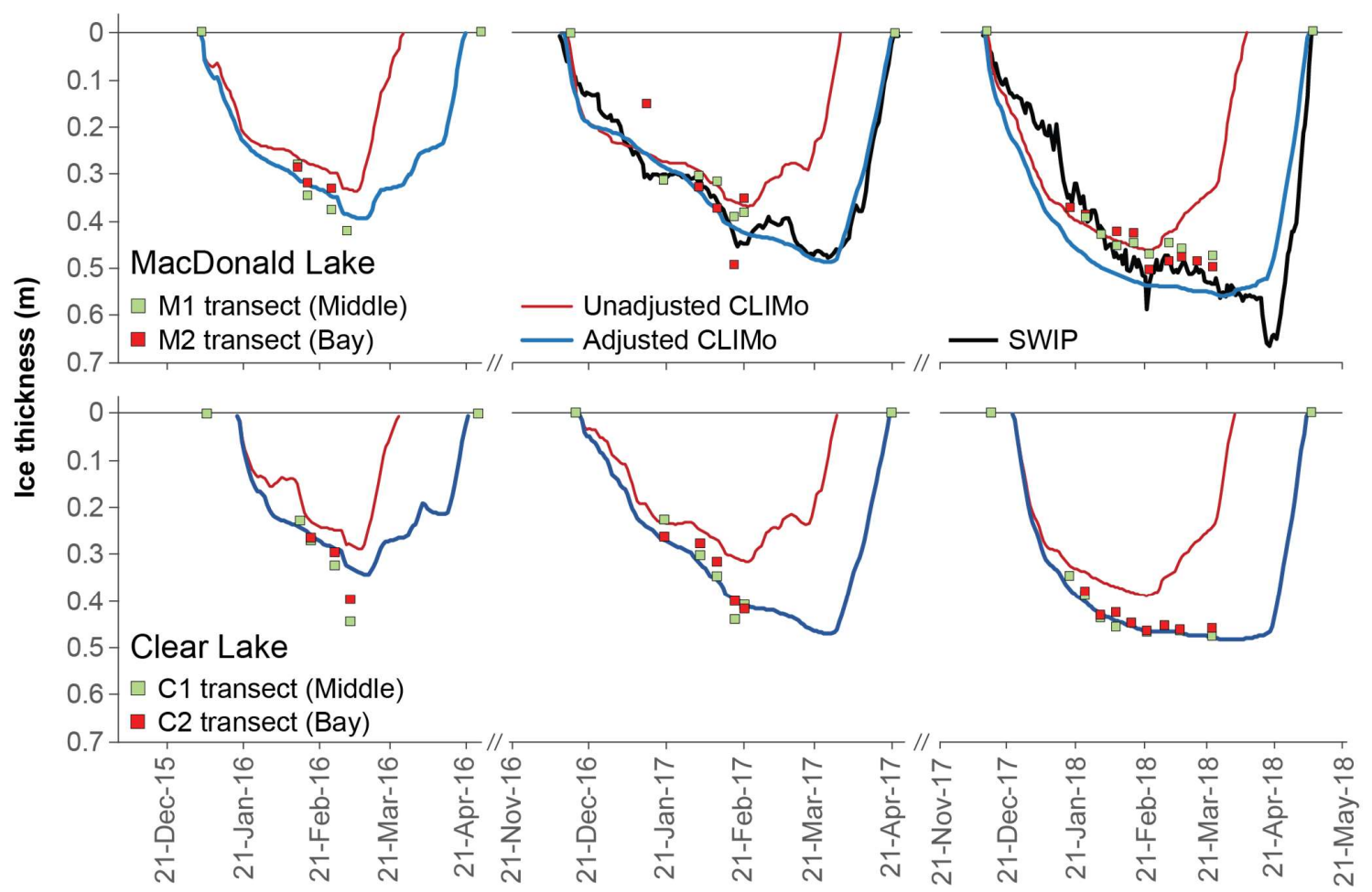

605 Figure 6. MacDonald and Clear Lake model runs for three consecutive seasons showing the unadjusted model (red line) and adjusted model (dark blue line), compared to the Shallow Water Ice Profiler (SWIP, black line), and manual auger measurements (M-1: MacDonald Lake transect, middle of lake; M-2: MacDonald Lake, over the SWIP; C-1: Clear Lake, middle of Lake and C-2: Clear Lake, sheltered bay).

Tables

Table 1. End of season snow survey mean (standard deviation; SD) of snow depth (cm) and density (kg $\mathrm{m}^{3}$ ) for Small Lake, NU.

\begin{tabular}{l|rrc}
\hline \multicolumn{1}{l}{ Year } & Snow Depth (cm) & Snow Density $\left(\mathbf{k g ~ m}^{-\mathbf{3}}\right)$ \\
\hline $\mathbf{2 0 1 6}$ & 22-May & $17.2(11.8)$ & $356.5(64.4)$ \\
$\mathbf{2 0 1 8}$ & 16-May & $11.4(21.5)$ & $307.7(29.9)$ \\
\hline
\end{tabular}


https://doi.org/10.5194/hess-2020-156

Hydrology and

Preprint. Discussion started: 27 April 2020

(c) Author(s) 2020. CC BY 4.0 License.

Table 2. Average bi-weekly snow density $\left(\mathrm{kg} \mathrm{m}^{3}\right)$ from the Canadian Snow CD and weekly average of on-ice sampled snow depth (cm) and snow density $\left(\mathrm{kg} \mathrm{m}^{-3}\right)$ for 2015-2016, 2016-2017, and 2017-2018 for MacDonald Lake and Clear Lake.

\begin{tabular}{|c|c|c|c|c|}
\hline Year & Day-Month & $\begin{array}{c}\text { Snow Depth } \\
\text { (cm) }\end{array}$ & Snow Density $\left(\mathrm{kg} \mathrm{m}^{-3}\right)$ & $\begin{array}{l}\text { Corresponding Average Bi- } \\
\text { weekly Canadian Snow CD } \\
\text { density }\left(\mathrm{kg} \mathrm{m}^{-3}\right)\end{array}$ \\
\hline \multirow[t]{5}{*}{2016} & 22-Jan & $13.9(1.3)$ & $196.2(64.3)$ & 204 \\
\hline & 12-Feb & $8.8(2.4)$ & $183.5(35.6)$ & 215 \\
\hline & $16-\mathrm{Feb}$ & $12.3(0.8)$ & $165.3(41.9)$ & 242 \\
\hline & 26-Feb & $8.5(2.1)$ & $305.2(73.9)$ & 242 \\
\hline & 04-Mar & $22.2(2.0)$ & $193.5(58.1)$ & 265 \\
\hline \multirow[t]{6}{*}{2017} & 13-Jan & $2.3(1.2)$ & $376.6(104.3)$ & 195 \\
\hline & 20-Jan & $3.0(0.9)$ & $424.7(60.8)$ & 204 \\
\hline & 03-Feb & $15.9(1.2)$ & -- & 215 \\
\hline & 10-Feb & $17.7(1.7)$ & $371.2(45.9)$ & 215 \\
\hline & 17-Feb & $29.9(4.2)$ & $206.5(43.3)$ & 242 \\
\hline & $21-\mathrm{Feb}$ & $5.1(4.1)$ & $307.4(107.7)$ & 242 \\
\hline \multirow[t]{9}{*}{2018} & 19-Jan & -- & $297.7(202.7)$ & 195 \\
\hline & 26-Jan & $1.6(1.0)$ & $102.0(30.9)$ & 204 \\
\hline & 02-Feb & $0.6(0.4)$ & $87.6(12.4)$ & 204 \\
\hline & 09-Feb & $6.7(0.2)$ & $163.3(39.9)$ & 215 \\
\hline & 16-Feb & $22.9(1.6)$ & $109.8(25.3)$ & 215 \\
\hline & 23-Feb & $16.2(1.6)$ & -- & 242 \\
\hline & 09-Mar & -- & $120.8(13.6)$ & 265 \\
\hline & 16-Mar & $7.3(1.7)$ & $450.3(420.4)$ & 265 \\
\hline & 23-Mar & $6.0(0.8)$ & $190.7(33.2)$ & 303 \\
\hline
\end{tabular}


https://doi.org/10.5194/hess-2020-156

Table 3. Data description for meteorological and snow data used for both study locations. Environment and Climate Change Canada (ECCC) data mainly used for the High Arctic sites and an on-shore Automatic Weather Station (AWS) primarily used for the temperate sites.

\begin{tabular}{lll}
\hline Variable & High Arctic & Temperate \\
\hline Air temperature & ECCC Resolute CARS (1958-2014), & On-shore AWS (2015 - 2018): HMP60 \\
& Resolute Bay A (2014-2018) & Temperature and Relative humidity probe \\
Relative humidity & ECCC Resolute CARS (1958-2014), & On-shore AWS (2015 - 2018): HMP60 \\
& Resolute Bay A (2014-2018) & Temperature and Relative humidity probe \\
Wind speed & ECCC Resolute CARS (1958-2014), & On-shore AWS (2015-2018): RM Young Wind \\
& Resolute Bay A (2014-2018) & Monitor \\
Snow depth & ECCC Resolute CARS (1958-2014), & On-shore AWS (2015 - 2018): SR50A Sonic \\
& Resolute Bay A (2014-2018) & Ranging Sensor \\
Cloud amount & ECCC 1958-2018 & MODIS MOD08_D3: Cloud Fraction (Daily \\
& & 1km product) \\
Snow density & ECCC: Snow CD & ECCC: Snow CD \\
& End-of-season snow survey's (Small & Field survey’s weekly, 2016-2018 snow \\
& Lake) May 22, 2016 \& May 16, 2018 & seasons \\
\hline
\end{tabular}

\section{OTHER}

Solar radiation

CNR4 Net Radiometer (2018-2019)

Solarmeter ${ }^{\circledR}$ Model 10.0 Global Power Meter (weekly, 2018-2019)

Barometric pressure

On-shore AWS (2015 - 2018): (CS106

Barometric Pressure Sensor) 
https://doi.org/10.5194/hess-2020-156

Preprint. Discussion started: 27 April 2020

(c) Author(s) 2020. CC BY 4.0 License.

Table 4. Comparison between simulated complete ice-on and ice-off dates and those observed from the digital camera at Small Lake, NU between 2016 and 2018.

\begin{tabular}{|c|c|c|c|c|c|c|c|c|}
\hline Year & $\begin{array}{l}\text { Ice-on } \\
\text { (50\% snow } \\
\text { cover) }\end{array}$ & $\begin{array}{l}\text { Ice-on (No } \\
\text { Snow } \\
\text { Cover) }\end{array}$ & $\begin{array}{l}\text { Observed } \\
\text { First } \\
\text { Presence } \\
\text { of Ice }\end{array}$ & $\begin{array}{l}\text { Complete } \\
\text { Ice-on }\end{array}$ & $\begin{array}{c}\text { Ice-off } \\
(50 \% \text { snow } \\
\text { cover })\end{array}$ & $\begin{array}{c}\text { Ice-off (No } \\
\text { Snow } \\
\text { Cover) }\end{array}$ & $\begin{array}{c}\text { Observed } \\
\text { First } \\
\text { Presence of } \\
\text { Open Water } \\
\text { (e.g. } \\
\text { Ponding, } \\
\text { moat } \\
\text { formation) } \\
\end{array}$ & $\begin{array}{c}\text { Complete } \\
\text { Ice-off }\end{array}$ \\
\hline 2015-2016 & -- & -- & -- & -- & 19-Jul & 27-Jul & 17-Jun & 21-Jul \\
\hline 2016-2017 & 12-Sep & 12-Sep & 12-Sep & 28-Sep & 8-Aug & 15-Aug & -- & 1-Aug \\
\hline 2017-2018 & 9-Sep & 8-Sep & 8-Sep & 12-Sep & 27-Jul & 10-Aug & 16-Jun & 6-Aug \\
\hline
\end{tabular}

630

Table 5. Validation (Mean Absolute Error; MAE) results of simulated ice-on and ice-off dates compared to the first observed complete ice cover date and ice-off date from the digital camera at Small Lake, NU between 2016 and 2018.

\begin{tabular}{l|ccl}
\hline & \multicolumn{2}{c}{$50 \%$ Snow Cover - } & \multicolumn{2}{l}{$\begin{array}{l}\text { No Snow Cover - } \\
\text { MAE }\end{array}$} \\
\hline $\begin{array}{l}\text { MAE } \\
\text { Compete Ice-on }\end{array}$ & 1 & 0 \\
Ice-off & 6 & 8 \\
\hline
\end{tabular}

635 Table 6. Validation results $(\mathrm{Ia}=$ Index of agreement, $\mathrm{MAE}=$ mean absolute error, $\mathrm{MBE}=$ mean bias error $)$ of simulated complete ice-on and ice-off dates to the observed complete ice-on and ice-off dates from the CID from 1962 to 1994 and the observed date of first complete ice cover and ice-off from the digital camera at Resolute Lake, from 2017 to 2018.

\begin{tabular}{c|cc}
\hline Complete Ice-on & $\mathbf{5 0 \%}$ Snow Cover & No Snow Cover \\
\hline Ia $_{\mathbf{a}}$ & 0.65 & 0.79 \\
MBE (days) & -3 & -4 \\
MAE (days) & 6 & 6 \\
\hline Ice-off & $\mathbf{5 0 \%}$ Snow Cover & No Snow Cover \\
\hline I $_{\mathbf{a}}$ & 0.75 & 0.77 \\
MBE (days) & -2 & 7 \\
MAE (days) & 8 & 8 \\
\hline
\end{tabular}


https://doi.org/10.5194/hess-2020-156

Table 7. Observed and simulated ice-on/off dates for MacDonald Lake.

\begin{tabular}{|c|c|c|c|c|c|c|c|c|}
\hline \multicolumn{3}{|c|}{$\begin{array}{l}\text { Digital } \\
\text { Camera }\end{array}$} & \multicolumn{2}{|c|}{ SWIP } & \multicolumn{2}{|c|}{$\begin{array}{c}\text { Simulation: MacDonald } \\
\text { Lake }\end{array}$} & \multicolumn{2}{|c|}{$\begin{array}{l}\text { Adjusted Simulation: } \\
\text { MacDonald Lake }\end{array}$} \\
\hline Study Year & Ice-On & Ice-off & Ice-On & Ice-off & Ice-On & Ice-off & Ice-On & Ice-off \\
\hline 2015-2016 & 4-Jan & 27-Apr & & & 4-Jan & 26-Mar & 4-Jan & 20-Apr \\
\hline 2016-2017 & 16-Dec & 22-Apr & 16-Dec & $21 \mathrm{Apr}$ & 13-Dec & 31-Mar & 13-Dec & 20-Apr \\
\hline 2017-2018 & 12-Dec & 8-May & 12-Dec & 7-May & 13-Dec & 8-Apr & 13-Dec & 6-May \\
\hline \multicolumn{5}{|c|}{$M A E$ (days) digital camera } & 1 & 28 & 1 & 4 \\
\hline \multicolumn{5}{|c|}{$M A E$ (days) SWIP } & 2 & 25 & 2 & 1 \\
\hline
\end{tabular}

Table 8. Observed, simulated and adjusted simulated ice-on and off dates for Clear Lake.

\begin{tabular}{|c|c|c|c|c|c|c|}
\hline \multirow[b]{2}{*}{ Study Year } & \multicolumn{2}{|c|}{ Digital Camera } & \multicolumn{2}{|c|}{$\begin{array}{l}\text { Simulation: } \\
\text { Clear Lake }\end{array}$} & \multicolumn{2}{|c|}{$\begin{array}{c}\text { Adjusted Simulation: } \\
\text { Clear Lake }\end{array}$} \\
\hline & Ice-On & Ice-off & Ice-On & Ice-off & Ice-On & Ice-off \\
\hline 2015-2016 & 5-Jan & 24-Apr & 18-Jan & 21-Mar & 18-Jan & 19-Apr \\
\hline 2016-2017 & 16-Dec & 20-Apr & 18-Dec & 29-Mar & 15-Dec & 19-Apr \\
\hline 2017-2018 & 11-Dec & 8-May & 25-Dec & 11-Apr & 18-Dec & 6-May \\
\hline \multicolumn{3}{|c|}{ MAE (days) digital camera } & 10 & 30 & 7 & 2 \\
\hline
\end{tabular}


https://doi.org/10.5194/hess-2020-156

660 Table 9. Observed thickness versus unadjusted model thickness MAE in cm for study lakes M-1: MacDonald Lake transect, middle of lake; M-2: MacDonald Lake, over the SWIP; C-1: Clear Lake, middle of Lake and C-2: Clear Lake, sheltered bay.

\begin{tabular}{l|llllllll}
\hline \multicolumn{3}{c}{ Unadjusted simulations } & \multicolumn{3}{c}{ Adjusted simulations } \\
\hline Study Year & M-1 & $\mathbf{M - 2}$ & $\mathbf{C - 1}$ & $\mathbf{C - 2}$ & $\mathbf{M - 1}$ & $\mathbf{M - 2}$ & $\mathbf{C - 1}$ & $\mathbf{C - 2}$ \\
& $(\mathbf{c m})$ & $\mathbf{( c m )}$ & $\mathbf{( c m )}$ & $\mathbf{( c m )}$ & $\mathbf{( c m )}$ & $\mathbf{( c m )}$ & $\mathbf{( c m )}$ & $(\mathbf{c m})$ \\
\hline $\mathbf{2 0 1 5 - 2 0 1 6}$ & 6.7 & 3.5 & 8.6 & 7.2 & 3.0 & 1.4 & 4.8 & 3.1 \\
$\mathbf{2 0 1 6 - 2 0 1 7}$ & 2.0 & 6.3 & 7.7 & 6.5 & 3.7 & 4.9 & 2.3 & 2.0 \\
$\mathbf{2 0 1 7 - 2 0 1 8}$ & 3.6 & 6.4 & 10.2 & 10.4 & 6.8 & 6.1 & 1.0 & 1.0 \\
\hline Overall & 4.1 & 5.2 & 8.8 & 8.0 & 4.5 & 4.1 & 2.7 & 2.0 \\
\hline
\end{tabular}

Table 10. Model performance and error statistics for observed (SWIP) compared to simulated ice thickness for MacDonald Lake.

\begin{tabular}{l|lll|lcc}
\hline \multicolumn{3}{c|}{ CLIMo vs. SWIP } & \multicolumn{3}{c}{ Adjusted CLIMo vs. SWIP } \\
\hline Study Year & Ia & MBE (cm) & MAE (cm) & Ia & MBE (cm) & MAE (cm) \\
\hline $\mathbf{2 0 1 6 - 2 0 1 7}$ & 0.62 & -9.9 & 11.2 & 0.98 & 2.0 & 2.7 \\
$\mathbf{2 0 1 7 - 2 0 1 8}$ & 0.50 & -13.7 & 18.1 & 0.92 & 1.9 & 7.2 \\
\hline
\end{tabular}

